\title{
The use of digital photography for the definition of coastal biotopes in Azores
}

\author{
N. V. Álvaro • F. F. M. M. Wallenstein · A. I. Neto · E. M. Nogueira • \\ J. Ferreira $\cdot$ C. I. Santos $\cdot$ A. F. Amaral
}

Received: 17 October 2006/Revised: 9 May 2007 / Accepted: 7 June 2007 / Published online: 18 July 2007

(C) Springer Science+Business Media B.V. 2007

\begin{abstract}
Sampling benthic communities usually requires intensive field and lab work which is generally performed by skilled staff. In algal dominated communities, like those on the shores of the Azores, biotope characterization studies focused on the more conspicuous algae categories, thus reducing the skills required for species identification. The present study compares in situ quadrat quantifications done by a skilled reader, with computer based quadrat quantifications using digital photographic records of the same areas read in situ, accomplished by skilled and nonskilled readers. The study was conducted inter- and subtidally at various shore heights/depths. Quantification of algal coverage, both in situ and computer based, used the point to point method with quadrats of $0.25 \mathrm{~m} \times 0.25 \mathrm{~m}$ for the intertidal, and $0.50 \mathrm{~m} \times 0.50 \mathrm{~m}$ for the subtidal surveys, both subdivided into 36 intersection points. Significant differences were found
\end{abstract}

Handling editor: K. Martens

Electronic supplementary material The online version of this article (doi:10.1007/s10750-007-9064-7) contains supplementary material, which is available to authorized users.

N. V. Álvaro · F. F. M. M. Wallenstein ( $₫)$.

A. I. Neto · E. M. Nogueira · J. Ferreira .

C. I. Santos - A. F. Amaral

Secção de Biologia Marinha, Laboratório de Ficologia, CIRN, Departamento de Biologia, Universidade dos Açores, Apartado 1422, Ponta Delgada, São MiguelAçores 9501-801, Portugal

e-mail: fmacedo@notes.uac.pt between in situ readings and computer based readings of photographic records conducted both by experienced and inexperienced readers. Biotopes identified using in situ data and image based data differ both for the subtidal and intertidal.

Keywords Algae - Quantification · Littoral biotopes - Digital image

\section{Introduction}

During the last decade there has been great effort in finding time effective and non-destructive research methods to reduce expert time and involvement in ecological field surveys (Turnbull \& Davies, 2001). Photography and video are examples of such methods, and digital image quality increase allows the collection of high resolution images that can be immediately discarded when not meeting the desired results. Its application is wide, ranging from remote sensing of wide areas using satellite and plain photography to photo microscopy. In many cases it is easier and cheaper to use good quality images rather than to go into the field to record species and/or other environmental features. Digital images have been used widely in biological and ecological studies, e.g. as a tool to monitor animal behaviour in Lobsigerl et al. (1986), Van Rooij \& Videler (1996) and Ishii et al. (1998). Magorrian \& Service (1998) and Pech et al. (2004) used digital imagery to assess and quantify benthic 
organisms. Norris et al. (1997) used video images to estimate seagrass beds coverage, and more recently Bullimore \& Hiscock (2001) used photography to monitor sublittoral rock biotopes and Ducrotoy \& Simpson (2001) to monitor algal bed coverage. The latter refers the importance of using image in surveys that consider wide ecological functional groups of algae that structure benthic communities, and emphasizes the use of photography in enabling unskilled fieldworkers' participation, thus restricting the use of experts in the data processing.

In the Azores there have been recent developments in biotope definition and spatial distribution (Wallenstein \& Neto, 2006; Wallenstein et al., in press; Wallenstein et al., submitted), based on broad ecological categories that are easily recognizable by unskilled surveyors. This classification and the methodologies used were developed with coastal management purposes in mind to assess biotope coverage by existing protected areas. These methodologies were developed to be implemented by surveyors with limited skills in algae taxonomy. The use of digital images is seen as a means to further reduce the involvement of skilled field surveyors in the collection of biotic data for biotope definition, and thus increase its feasibility by official agencies staff. With the purpose of defining biotopes based on broad ecological categories the present study was developed on Graciosa Island (Azores) and aimed at verifying: (i) the possibility of using digital imagery and thus dismiss skilled field surveyors, and (ii) the need to involve skilled surveyors in image based quantification of algae communities.

\section{Materials and methods}

\section{Location selection}

Rocky shore study sites around Graciosa Island were selected randomly by overlaying a $2 \mathrm{~km} \times 2 \mathrm{~km}$ grid on a map of the island (Fig. 1). The grid intersections around the coastline created a pool of potential study sites. These were numbered 1 to 16 anticlockwise from Santa Cruz and survey sites were selected using random numbers. As most intersections did not fall directly on the coastline, survey sites were located by a north, south, east or west landward projection from a selected numbered intersection (see Fig. 1). The total number of sites to be studied was defined a priori to assure a balanced sampling design for both inter- and subtidal zones, considering substratum type and shore height as structuring factors for the intertidal (Wallenstein \& Neto, 2006; Wallenstein et al., submitted) and depth for the subtidal (Wallenstein et al., in press). A total of nine intertidal sites were surveyed, three for each substrate category (cobbles, boulders and bedrock), and at each site
Fig. 1 Graciosa Island with superimposed $2 \mathrm{~km} \times 2 \mathrm{~km}$ grid and indication of landward projection of numbered intersections

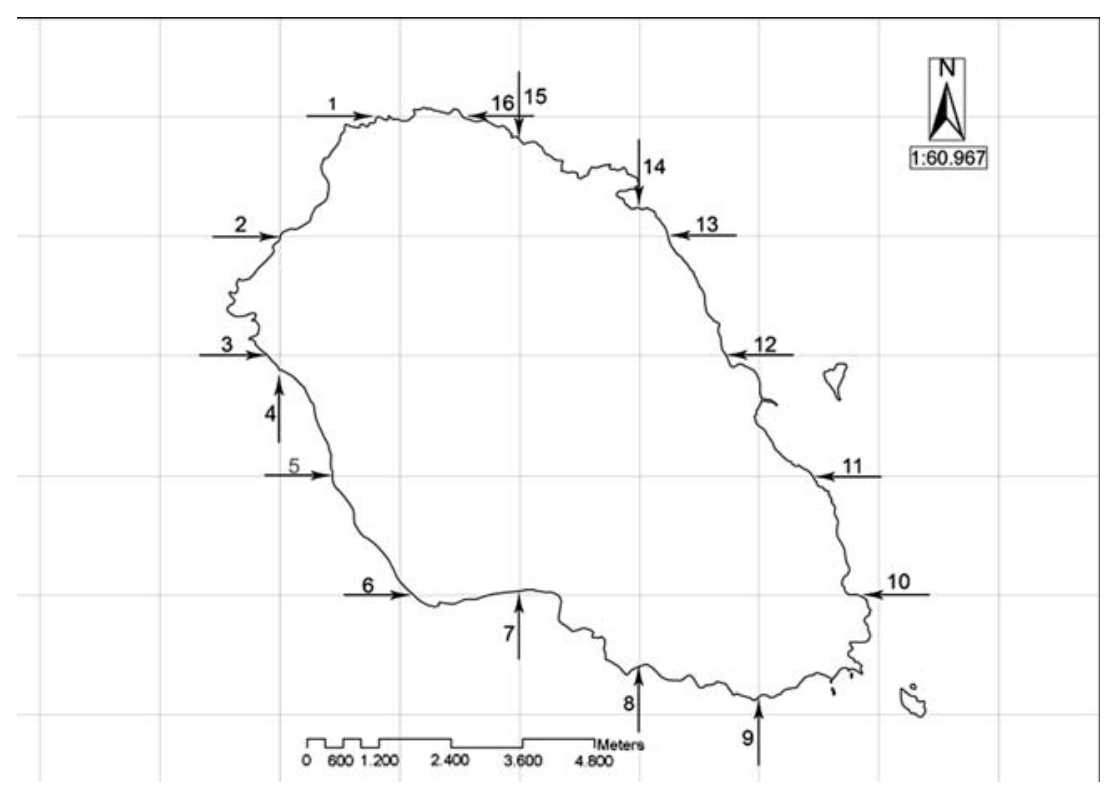


algae were quantified at three shore levels (L1-L3; see below in "Intertidal replication"). Subtidally, twelve sites were surveyed, three at each of four depth ranges (4-6 $\mathrm{m}, 12-14 \mathrm{~m}, 20-22 \mathrm{~m}$ and 28$30 \mathrm{~m})$. The survey was conducted throughout the months of June and July 2006.

Field work

\section{Subtidal}

Quantitative data on sessile organisms as algae, sponges, hydrozoans and bryozoans were gathered from nine replicate quadrats at each site: the first quadrat was placed next to the anchor of the boat at the mid depth level of the desired depth range (i.e. $5 \mathrm{~m} ; 13 \mathrm{~m} ; 21 \mathrm{~m} ; 29 \mathrm{~m}$ ); subsequent quadrats were placed at a random distance and direction from the first one (Wallenstein et al., in press).

\section{Intertidal}

Surveys followed the methodology of Wallenstein \& Neto (2006) and Wallenstein et al. (submitted). At each survey site three transects were laid down; the first one placed at a right angle to the shore line at the most central zone of the shore extension to be surveyed; the following two, parallel to the first one, were located randomly at a maximum distance of $9 \mathrm{~m}$. Shore height was divided into three equidistant levels for collecting quantitative data starting at the uppermost algae recorded on each transect, down to low water level. Level 1 (L1) at the lowest point of the intertidal immediately above low water level; level 3 (L3) where the first algae was recorded and level 2 (L2) at half distance between L1, and L3. Algae, barnacles and limpets were quantified within three replicate quadrats at each shore level. The first replicate quadrat was placed on the transect line, and the subsequent ones placed at a random distance and direction from the first one.

\section{In situ quantification and photographs}

Subtidal replicate quadrats [minimum sampling area of $0.50 \mathrm{~m} \times 0.50 \mathrm{~m}$ defined by Neto (1997)] and intertidal replicate quadrats [minimum sampling area of $0.25 \mathrm{~m} \times 0.25 \mathrm{~m}$ defined by Neto (1997)] were quantified in situ using the point-to-point method (Hawkins \& Jones, 1992) with 36 intersections (S data set) and subsequently photographed. Quantification consisted in recording the frequency of occurrence of each organism inside the quadrat (number of point intersections coinciding with each organism; maximum of 36). Photographs were taken with a SONY V3 camera inside a watertight casing attached to a stainless steel structure (see Fig. 2). Intertidal images covered the complete $0.25 \mathrm{~m} \times 0.25 \mathrm{~m}$ quadrat area, while subtidal $0.50 \mathrm{~m} \times 0.50 \mathrm{~m}$ quadrats were covered by a set of four $0.25 \mathrm{~m} \times 0.25 \mathrm{~m}$ images taken clockwise from the upper left corner (Fig. 3a).

Laboratory work

\section{Image treatment and quantification of organisms}

All images were adjusted for brightness and contrast with Adobe Photoshop 5. Subtidal $0.50 \mathrm{~m} \times 0.50 \mathrm{~m}$ images resulted from the composition of the respective sets of four $0.25 \mathrm{~m} \times 0.25 \mathrm{~m}$ partial images (see Fig. 3b). A 36 intersection grid was overlaid over the quantification area of each image (see Fig. 3c) and organisms quantified at the computer using the final composition (see Fig. 3d) following in situ procedures by the in situ reader [SR, a skilled operative to be used as a control when comparing in situ quantifications (S) with computer based quantifications], an inexperienced phycologist (IP) and an experienced phycologist (EP).

\section{Data treatment and analysis}

In situ and image based quantification frequency matrices were converted into percentage cover matrices by dividing frequency of occurrence of

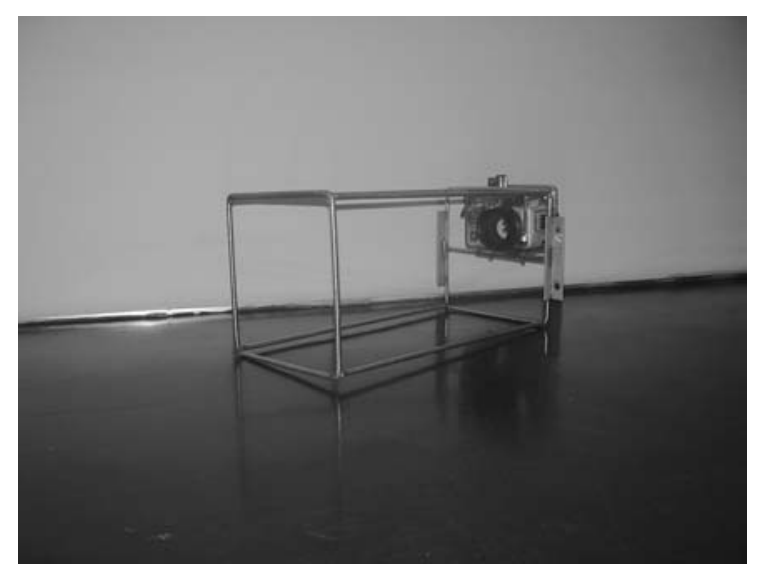

Fig. 2 Waterproof casing attached to stainless steel structure 
Fig. 3 Image collection and treatment process: (a) subtidal photographing sequence; (b) subtidal quadrat composition; (c) superimposition of quantifying grid over composed image; (d) final subtidal image (a)

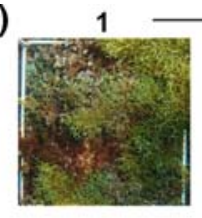

4

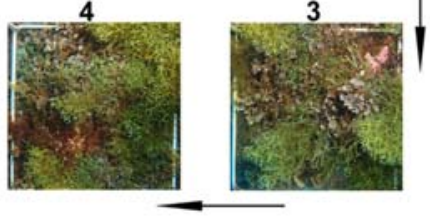

(c)

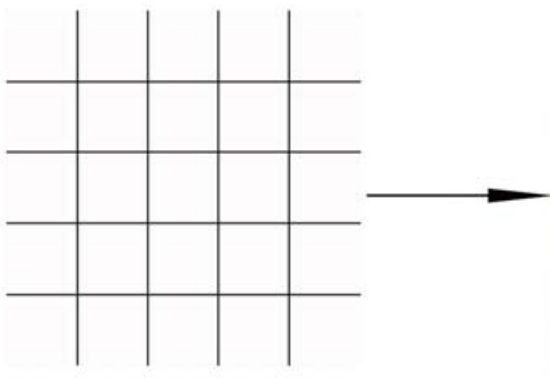

(d)

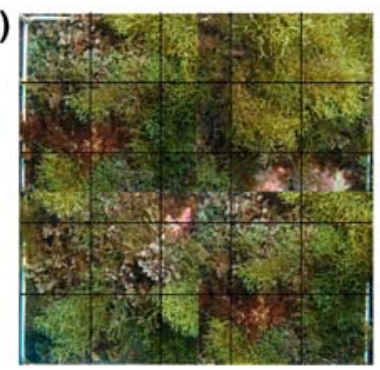

(b)
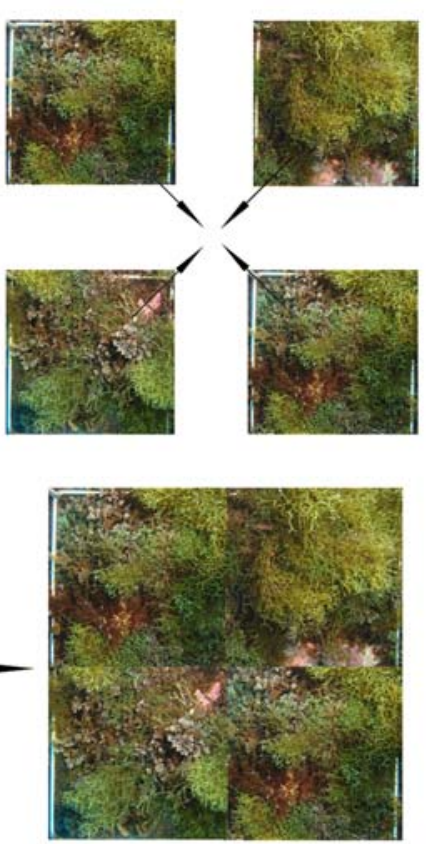

each species/ecological category inside each quadrat by the maximum possible occurrence per quadrat (36).

For each quadrat read in situ and at the computer by all readers percentage differences between in situ readings (S) and each computer based reading ( $S R$, IR and ER), and between different computer based readings were calculated using the formula:

$$
\frac{\sum_{\mathrm{i}=1}\left|x_{\mathrm{iRa}}-x_{\mathrm{iRb}}\right|}{72}, \quad \mathrm{a} \neq \mathrm{b},
$$

in which I-species/ecological categories; X-number of intersections in a quadrat $(\leq 36)$ attributed to species/ecological category $\mathrm{i}$, by reader $\mathrm{R} 1$ or $\mathrm{R} 2$; $\mathrm{Ra}$-reader a ( $\mathrm{S}$-in situ reading; $\mathrm{SR}$ - computer reading by in situ reader; ER — computer reading by experienced phycologist; IR-computer reading by inexperienced phycologist); $\mathrm{Rb}$-reader $\mathrm{b}(\mathrm{S}$-in situ reading; SR - computer reading by in situ reader; ER-computer reading by experienced phycologist; IR-computer reading by inexperienced phycologist); 72-maximum number of different intersections between two readings of the same quadrat $\left(36^{*} 2\right)$.

To test the hypothesis that there are no significant differences between image and in situ readings, data was analysed using analysis of variance (ANOVA). For subtidal data two fixed and orthogonal factors were considered: (1) reader (3 levels-in situ reader, inexperienced phycologist and experienced phycologist) and (2) depth (4 levels-29 m, $21 \mathrm{~m}, 13 \mathrm{~m}, 5 \mathrm{~m}$ ). Three fixed and orthogonal factors were considered for intertidal data: (1) reader (3 levels - in situ reader, inexperienced phycologist and experienced phycologist); (2) substratum (3 levels-bedrock, boulders and 
cobbles) and (3) shore height (3 levels-L1, L2 and L3). Cochran's test (Winer, 1971) was used to test for heterogeneity of variance and to check for the need to transform data. Multiple comparisons of levels within significant factors were made using Student Newman Keuls (SNK) tests.

Biotope definition was achieved with PRIMER software (Clarke \& Warwick, 2001) following the guidelines defined by Wallenstein et al. (in press) and were applied to the four quantification data sets (S, SR, IP and EP) to compare results and assess image quantification applicability for biotope definition.

\section{Results}

Subtidal

Average percentage deviation between subtidal image and in situ readings ranged between $15 \%$ and $20 \%$ with high standard deviation values associated (Table 1). The highest-average deviation values were associated to both extreme depth levels ( $29 \mathrm{~m}$ and $5 \mathrm{~m}$ ), while the

Table 1 Average percentage deviation $( \pm 1 \mathrm{sd})$ between in situ subtidal quantitative data (S) and image derived data by the in situ reader (SR), by an inexperienced phycologist (IP), and an experienced phycologist (EP) at four subtidal depth levels

\begin{tabular}{llll}
\hline & SR & IP & EP \\
\hline $29 \mathrm{~m}$ & $15.8( \pm 14.5)$ & $21.9( \pm 19.2)$ & $20.4( \pm 18.0)$ \\
$21 \mathrm{~m}$ & $13.6( \pm 13.1)$ & $17.1( \pm 11.0)$ & $16.7( \pm 14.7)$ \\
$13 \mathrm{~m}$ & $7.8( \pm 5.8)$ & $14.2( \pm 9.5)$ & $15.5( \pm 16.2)$ \\
$5 \mathrm{~m}$ & $16.2( \pm 13.2)$ & $26.4( \pm 19.7)$ & $18.3( \pm 19.1)$ \\
Global & $13.3( \pm 11.6)$ & $19.9( \pm 14.8)$ & $17.7( \pm 17.0)$ \\
\hline
\end{tabular}

lowest ones were associated to the $13 \mathrm{~m}$ depth level. When quantifying communities based on digital images data from IP presented higher deviations relative to that from $\mathrm{S}$, while data from $\mathrm{SR}$ presented lower average differences globally and at all depth levels. ANOVA results (Table 2) revealed that the interaction between reader and depth is not significant and that differences between depths were significant as were differences between deviations from the three image readings relative to in situ readings. SNK test indicated that SR deviations were similar to those of EP, while both of them differed from IP. Biotopes defined using both $\mathrm{S}$ data and SR data turned out to be the same (Table 3a), differing from those resulting from EP (Table 3b) and those of IP (Table 3c). Both EP and IP added new ecological categories to the biotopes defined with $\mathrm{S}$ data, but did not omit any of the previously found by the in situ surveyor.

\section{Intertidal}

Average percentage deviation between intertidal image and in situ readings were generally higher than for the subtidal ranging between $18 \%$ and $80 \%$ with high-standard deviation values associated (Table 4). The lowest values were associated with cobble locations followed by boulders, and with data from bedrock presenting the highest average deviations. Higher average deviations were shown at the intermediate shore level (L2) than at lower (L1) and higher (L3) levels. When comparing readers IP presented higher deviations relative to $S$, while SR presented overall lower average differences at all shore levels and for all substrata.

ANOVA revealed that all factors are significant as were all interactions between them (Table 5). The interaction between reader, shore height and substra-

Table 2 Two factor ANOVA of deviations in subtidal image derived quantitative data versus in situ quantitative data

\begin{tabular}{llllll}
\hline Source & Degrees of freedom & Mean squares & F ratio & P & F ratio versus \\
\hline Reader & 2 & 624.3827 & 5.11 & 0.0066 & Residual \\
Depth & 3 & 533.8765 & 4.37 & 0.0049 & Residual \\
Reader $\times$ depth & 6 & 71.9877 & 0.59 & 0.7390 & Residual \\
Residual & 312 & 122.1918 & & & \\
Total & 323 & & & & \\
SNK tests of reader & & & & & \\
$\quad$ SR = EP $\neq$ IP & & & & &
\end{tabular}

No transformation of data: Cochran's test $=0.1426$ (not significant) 
Table 3 Subtidal biotopes obtained from in situ data and image derived data

\begin{tabular}{|c|c|c|c|c|c|c|c|}
\hline $\begin{array}{l}\text { Shore } \\
\text { level }\end{array}$ & \multicolumn{7}{|c|}{ Species/ecological categories } \\
\hline \multicolumn{8}{|c|}{ a) in situ $(S)$ data biotopes $=$ image derived $(S R)$ data biotopes } \\
\hline $5 \mathrm{~m}$ & $\begin{array}{l}\text { Dictyota } \\
\text { spp. }\end{array}$ & $\begin{array}{l}\text { Zonaria } \\
\quad \text { tournefortii }\end{array}$ & $\begin{array}{l}\text { Asparagopsis } \\
\text { spp. }\end{array}$ & Stypocaulon type & & & \\
\hline $13 \mathrm{~m}$ & $\begin{array}{l}\text { Dictyota } \\
\text { spp. }\end{array}$ & $\begin{array}{l}\text { Zonaria } \\
\quad \text { tournefortii }\end{array}$ & $\begin{array}{l}\text { Asparagopsis } \\
\text { spp. }\end{array}$ & & & & \\
\hline $21 \mathrm{~m}$ & $\begin{array}{l}\text { Dictyota } \\
\text { spp. }\end{array}$ & $\begin{array}{l}\text { Zonaria } \\
\quad \text { tournefortii }\end{array}$ & $\begin{array}{l}\text { Asparagopsis } \\
\text { spp. }\end{array}$ & & & & \\
\hline $29 \mathrm{~m}$ & $\begin{array}{l}\text { Dictyota } \\
\text { spp. }\end{array}$ & $\begin{array}{l}\text { Zonaria } \\
\quad \text { tournefortii }\end{array}$ & & & & & \\
\hline \multicolumn{8}{|c|}{ b) Image derived (EP) data biotopes } \\
\hline $5 \mathrm{~m}$ & $\begin{array}{l}\text { Dictyota } \\
\text { spp. }\end{array}$ & $\begin{array}{l}\text { Zonaria } \\
\quad \text { tournefortii }\end{array}$ & $\begin{array}{l}\text { Asparagopsis } \\
\text { spp. }\end{array}$ & Stypocaulon type & $\begin{array}{l}\text { Non calcareous } \\
\text { turf }\end{array}$ & & \\
\hline $13 \mathrm{~m}$ & $\begin{array}{l}\text { Dictyota } \\
\text { spp. }\end{array}$ & $\begin{array}{l}\text { Zonaria } \\
\quad \text { tournefortii }\end{array}$ & $\begin{array}{l}\text { Asparagopsis } \\
\text { spp. }\end{array}$ & & & & \\
\hline $21 \mathrm{~m}$ & $\begin{array}{l}\text { Dictyota } \\
\text { spp. }\end{array}$ & $\begin{array}{l}\text { Zonaria } \\
\quad \text { tournefortii }\end{array}$ & $\begin{array}{l}\text { Asparagopsis } \\
\text { spp. }\end{array}$ & & & & \\
\hline $29 \mathrm{~m}$ & $\begin{array}{l}\text { Dictyota } \\
\text { spp. }\end{array}$ & $\begin{array}{l}\text { Zonaria } \\
\quad \text { tournefortii }\end{array}$ & & $\begin{array}{l}\text { Acrosorium } \\
\text { venulosum }\end{array}$ & Calcareous crust & & \\
\hline \multicolumn{8}{|c|}{ c) Image derived (IP) data biotopes } \\
\hline $5 \mathrm{~m}$ & $\begin{array}{l}\text { Dictyota } \\
\text { spp. }\end{array}$ & $\begin{array}{l}\text { Zonaria } \\
\quad \text { tournefortii }\end{array}$ & $\begin{array}{l}\text { Asparagopsis } \\
\quad \text { spp. }\end{array}$ & Stypocaulon type & $\begin{array}{l}\text { Non calcareous } \\
\text { turf }\end{array}$ & $\begin{array}{l}\text { Calcareous } \\
\text { turf }\end{array}$ & $\begin{array}{l}\text { Green } \\
\text { algae }\end{array}$ \\
\hline $13 \mathrm{~m}$ & $\begin{array}{l}\text { Dictyota } \\
\text { spp. }\end{array}$ & $\begin{array}{l}\text { Zonaria } \\
\quad \text { tournefortii }\end{array}$ & $\begin{array}{l}\text { Asparagopsis } \\
\text { spp. }\end{array}$ & & $\begin{array}{l}\text { Non calcareous } \\
\text { turf }\end{array}$ & & \\
\hline $21 \mathrm{~m}$ & $\begin{array}{l}\text { Dictyota } \\
\text { spp. }\end{array}$ & $\begin{array}{l}\text { Zonaria } \\
\quad \text { tournefortii }\end{array}$ & $\begin{array}{l}\text { Asparagopsis } \\
\text { spp. }\end{array}$ & & $\begin{array}{l}\text { Non calcareous } \\
\text { turf }\end{array}$ & & \\
\hline $29 \mathrm{~m}$ & $\begin{array}{l}\text { Dictyota } \\
\text { spp. }\end{array}$ & $\begin{array}{l}\text { Zonaria } \\
\quad \text { tournefortii }\end{array}$ & & & $\begin{array}{l}\text { Non calcareous } \\
\text { turf }\end{array}$ & $\begin{array}{l}\text { Calcareous } \\
\text { turf }\end{array}$ & \\
\hline
\end{tabular}

tum is the one that reflects all factors, as such SNK tests were chosen to focus on this interaction to check significant differences between readers at all combinations of substrate and shore height. Although in most cases SR was similar to EP, and both of them differed from IP, it was not possible to define a generalized pattern as for subtidal observations, (Table 5). Patterns observed were restricted to shore levels L3 and L5 at boulder and cobble locations: bedrock was the substrate that caused higher variability in similarity/dissimilarity between readers.

Intertidal biotopes defined using $\mathrm{S}$ data (Table 6a) and SR data (Table 6b) differed with an additional category for shore height L2 (Calcareous turf). Biotopes defined from EP data (Table 6c) omitted two categories compared with $\mathrm{S}$ data biotopes (calcareous turf and Laurencia type from shore height L2). IP data (Table 6d) lacked three categories (Green algae from L3, Laurencia type from shore height L2 and Cystoseira spp. from shore height L1) while recognising another one (Pterocladiella capillacea on shore heights L2 and L3). When compared with S data biotopes, both EP and IP data lost ecological categories, while SR data added one.

\section{Discussion}

Subtidal

\section{Applicability of methods}

Differences between all image readers (SR, EP and IP) and in situ readings (S) ranged from values that are acceptable (average - standard deviation $\approx 5 \%$ ) to values that reached an unacceptable error (average + standard deviation $\approx 50 \%$ ). From these values it would be difficult to decide whether or not to use 
Table 4 Average percentage deviation $( \pm 1 \mathrm{sd})$ between in situ intertidal data $(\mathrm{S})$ and image derived data by the in situ reader (SR), by an inexperienced phycologist (IP), and an experienced phycologist (EP) at three shore height levels (L1, L2 and L3) from three substrate categories (bedrock, boulders and cobbles)

\begin{tabular}{llll}
\hline & SR & IP & EP \\
\hline Bedrock & & & \\
L1 & $29.3( \pm 21.9)$ & $48.5( \pm 27.6)$ & $38.1( \pm 32.0)$ \\
L2 & $47.4( \pm 31.7)$ & $51.8( \pm 21.8)$ & $70.1( \pm 29.8)$ \\
L3 & $32.8( \pm 21.9)$ & $69.8( \pm 23.9)$ & $39.8( \pm 34.1)$ \\
Global & $36.5( \pm 25.2)$ & $56.7( \pm 24.4)$ & $49.3( \pm 31.9)$ \\
Boulders & & & \\
L1 & $26.9( \pm 17.7)$ & $41.8( \pm 24.8)$ & $43.7( \pm 27.2)$ \\
L2 & $30.8( \pm 18.6)$ & $65.1( \pm 19.6)$ & $41.6( \pm 21.8)$ \\
L3 & $20.3( \pm 16.5)$ & $81.6( \pm 16.9)$ & $21.8( \pm 23.8)$ \\
Global & $26.0( \pm 17.6)$ & $62.8( \pm 20.4)$ & $35.7( \pm 24.3)$ \\
Cobbles & & & \\
L1 & $21.3( \pm 17.8)$ & $31.6( \pm 17.8)$ & $21.8( \pm 23.0)$ \\
L2 & $20.32( \pm 10.7)$ & $42.3( \pm 24.3)$ & $22.1( \pm 17.8)$ \\
L3 & $18.0( \pm 23.8)$ & $75.5( \pm 17.4)$ & $13.9( \pm 19.7)$ \\
Global & $19.9( \pm 17.4)$ & $49.8( \pm 19.8)$ & $19.3( \pm 20.2)$ \\
\hline
\end{tabular}

direct field observations or image observations for quantifying benthic algae communities. The fact that the in situ reader image readings (SR) showed less deviation than all other readers compared to in situ quantitative data (S) could be an argument to use a skilled field surveyor. The lower deviation may reflect a previous knowledge of subtidal communities by the SR, and could have influenced the results. Since average deviations of the SR are close to those of the EP, confirmed by the ANOVA SNK tests, this suggests that having experienced phycologist computer image readings can replace the in situ reader. Both average differences and SNK tests indicated that IP data differs significantly from the other two, thus demonstrating that a IP would not be a satisfactory replacement for a SR or EP in order to gather reliable quantitative data from images. Biotopes defined by both the EP and the IP differed from those defined by SR and $\mathrm{S}$. This reflects the danger of dismissing the SR, even if not differing significantly from the experienced phycologist EP.

As a direct consequence of this the comparison of subtidal biotopes obtained using the methods of Wallenstein et al. (in press) in field studies on São Miguel, Santa Maria and Graciosa Islands, is only possible if the in situ surveyor is kept throughout the whole survey to assure that the results are comparable. If it is decided to read digital images instead of a skilled surveyor in situ, this should be implemented from the beginning of the survey and kept throughout the whole study to assure comparability of results. However, the exclusion of a skilled phycologist from an image based benthic community characterization survey is not recom-

Table 5 Three factor ANOVA of deviations in intertidal image quantification versus in situ quantification. No transformation of data: Cochran's test $=0.0812$ (not significant)

\begin{tabular}{|c|c|c|c|c|c|}
\hline Source & Degrees of freedom & Mean Squares & $\mathrm{F}$ ratio & $\mathrm{P}$ & $\mathrm{F}$ ratio versus \\
\hline Reader & 2 & $28,621.4993$ & 100.52 & 0.0000 & Residual \\
\hline Substrate & 2 & $10,400.1043$ & 36.53 & 0.0000 & Residual \\
\hline Shore height & 2 & 3410.2977 & 11.98 & 0.0000 & Residual \\
\hline Reader $\times$ substrat & 4 & 1935.2853 & 6.80 & 0.0000 & Residual \\
\hline Reader $\times$ shore height & 4 & 7372.9540 & 25.89 & 0.0000 & Residual \\
\hline Substrate $\times$ shore height & 4 & 984.7503 & 3.46 & 0.0082 & Residual \\
\hline Reader $\times$ substrate $\times$ shore height & 8 & 817.9160 & 2.87 & 0.0038 & Residual \\
\hline Residual & 702 & 284.7389 & & & \\
\hline Total & 728 & & & & \\
\hline \multicolumn{6}{|c|}{ SNK tests of reader $\times$ substrate $\times$ shore height } \\
\hline & $\mathrm{L} 1$ & L2 & L3 & & \\
\hline Bedrock & $\mathrm{SR}=\mathrm{EP} ; \mathrm{IP}=\mathrm{EP} ; \mathrm{SR} \neq \mathrm{IP}$ & $\mathrm{SR}=\mathrm{IP} \neq \mathrm{EP}$ & $\mathrm{SR}=\mathrm{EP} \neq \mathrm{IP}$ & & \\
\hline Boulders & $\mathrm{SR} \neq \mathrm{IP}=\mathrm{EP}$ & $\mathrm{SR}=\mathrm{EP} \neq \mathrm{IP}$ & $\mathrm{SR}=\mathrm{EP} \neq \mathrm{IP}$ & & \\
\hline Cobbles & $\mathrm{SR}=\mathrm{IP}=\mathrm{EP}$ & $\mathrm{SR}=\mathrm{EP} \neq \mathrm{IP}$ & $\mathrm{SR}=\mathrm{EP} \neq \mathrm{IP}$ & & \\
\hline
\end{tabular}


Table 6 Intertidal biotopes obtained with in situ readings and image derived readings

Shore level Species/ecological categories

a) S-In situ quantification biotopes

$\begin{array}{lllll}\text { L3 } & \text { Green algae } & \text { Barnacles } & \text { First stratum } & \text { Non calcareous turf } \\ \text { L2 } & \text { Calcareous Turf } & \text { Laurencia type } & \text { First stratum } & \text { Non calcareous turf } \\ \text { L1 } & \text { Calcareous Turf } & \text { Cystoseira } \text { spp. } & \text { Erect calcareous } & \text { Non calcareous turf }\end{array}$

b) SR-In situ reader image derived quantification biotopes

$\begin{array}{lllll}\text { L3 } & \text { Green algae } & \text { Barnacles } & \text { First stratum } & \text { Non calcareous turf } \\ \text { L2 } & \text { Calcareous turf } & \text { Laurencia type } & \text { First Stratum } & \text { Non calcareous turf Erect Calcareous } \\ \text { L1 } & \text { Calcareous turf } & \text { Cystoseira } \text { spp. } & & \text { Non calcareous turf Erect Calcareous }\end{array}$

c) EP-Experienced phycologist image derived quantification biotopes

\begin{tabular}{|c|c|c|c|}
\hline L3 & Green algae & Barnacles & First stratum \\
\hline L2 & & & First stratum \\
\hline
\end{tabular}

L1 Calcareous turf Cystoseira spp.
d) IP-Inexperienced phycologist image derived quantification biotopes

$\begin{array}{lllll}\text { L3 } & & \text { Barnacles } & \text { First stratum } & \text { Non calcareous turf } \\ \text { L2 } & \text { Calcareous turf } & \text { Pterocladiella capillacea } & & \text { Non calcareous turf } \\ \text { L1 } & \text { Calcareous turf } & \text { Pterocladiella capillacea } & \text { Erect Calcareous } & \text { Non calcareous turf }\end{array}$

mended, as also referred by Ducrotoy \& Simpson (2001) that state the need of an expert for the data processing phase.

\section{Technical problems}

Image quality may be the cause of the deviations encountered between in situ readings ( $\mathrm{S}$ ) and image based readings (SR, EP and IP), namely in subtidal studies using $0.50 \mathrm{~m} \times 0.50 \mathrm{~m}$ quantification quadrats that require fractionate photography (sets of four $0.25 \mathrm{~m} \times 0.25 \mathrm{~m}$ images) in situ, and posterior computer based composition for image based quantification of species. This process might result in a certain amount of error that is difficult to quantify (Fig. 3d), also referred to in the study of Singh et al. (1998) that defend its use when large areas of interest are needed within a single picture frame. Additionally, poor image quality will result from overexposure (Annex 1a) and increased water turbidity particularly noticeable at shallow depths where there is much water movement. Possibly indicating a direct causal relation, it is at shallow depth levels that most differences occurred between in situ readings (S) and image based readings (SR, EP and IP). Such noise can easily be removed if taken into consideration when photographing in further studies that intend to use image for benthic community characterization. Furthermore, at deeper subtidal levels there is a 'canopy effect' where frondose algae camouflage lower strata of bare rock, encrusting algae and turf forming algae used for attachment. In situ readings (S) are subject to this effect to a greater extent than image based readings (SR, EP and IP) due to the quadrat and its nylon mesh that flattens the canopy of vegetation against the substrata beneath. Since photographs are taken without the quantification quadrat, frondose algae are recorded in their natural position thus revealing a higher proportion of the lower attachment strata. Consequently the appearance of non calcareous turf, Acrosorium venulosum and calcareous crust, that are typical understrata components, and reflect greater accuracy in digital image data for biotope definition.

\section{Intertidal}

\section{Applicability of methods}

Average differences (as much as 90\%) between computer based image data and in situ quantitative data at intertidal levels are more variable than at the subtidal levels, thus increasing the level of uncertainty and thus the applicability of using digital 
images for such studies. Although also high, lower dissimilarities occur in data for less complex communities that characterize unstable rocky substrata (cobbles). Dissimilarity between in situ data increases with community complexity and substratum stability (e.g. boulders and bedrock); for shore height, midshore levels show greater differences between image and in situ data. Communities (biotopes) at this shore level are transitional between upper levels, where green algae are dominant but with low abundances, and lower levels, where turfs and some frondose algae co-dominate. As with subtidal data, SR data presents the lowest differences compared to $\mathrm{S}$ data, although not for all substrata and all shore levels. SNK results are not generally applicable, although the majority of cases indicate that EP and SR data are more similar than EP data is to IP data. This might suggest that a skilled field surveyor could be replaced by an image collector, while quantitative data would be obtained through the use of digital images by an experienced phycologist. However, since there isn't a generalized pattern between SR, EP and IP readings across substrata and shore level, the use of digital image could lead to unreliable results in some substratum and/or shore height categories.

\section{Technical problems}

Intertidal communities are more difficult to characterize using digital images as they are mainly composed of ecological categories differentiated with difficulty (e.g. calcareous and non calcareous turfs). Other aspects of image quality may affect data derived such as: high water retention creating light reflex making it difficult to diagnose species/ ecological categories (see Annex 1b); light incidence [e.g. absent on cloudy days (see Annex 1c) versus varying angle of incidence on sunny days causing differential shading (see Annex 1d)]; condensation inside the water proof camera (see Annex 1e); and wave action causing splash and spray on the camera's lens (see Annex 1f). Characterization studies that use image are widely applied to benthic habitat characterization, and are to some extent successful in characterizing large-scale macroinvertebrate associations that are easily identifiable at some distance (e.g. Barker et al., 1999; Collie et al., 2000; Kostylev et al., 2001; Lund-Hanson et al., 2004 and Tkachenko, 2005). However, few small scale studies exist that proved successful in characterizing algae based communities, as intended by the present work and used for monitoring purposes by Ducrotoy \& Simpson (2001).

\section{Final remarks}

The methodology proposed in the present paper proved to be efficient in subtidal surveys if implemented during the whole survey with the advantage of dismissing the experienced phycologist from the field and lowering the cost of short and long term monitoring plans and general ecological surveys, as suggested by Pech et al. (2004). Contrarily to the suggestion of Ducrotoy \& Simpson (2001), however, this method proved to be inadequate for intertidal surveys, which is likely to be related to the highly variable and patchy nature of Azorean intertidal communities (Neto, 2000). Nevertheless, further surveys of intertidal communities should consider the inclusion of photographic surveys and an effort should focus on eliminating image collection problems that are avoidable if the causes are considered at the planning stage.

Acknowledgements The authors wish to thank: Doctor José Azevedo for general discussions; Daniel Torrão, Dr. Ruben Couto and Dr. Marlene Terra for helping with field work and Dr. Ian Tittley, MSc. Gustavo Martins and the anonymous referees for advice and peer review of the paper. This work was supported partially by the project POCTIMGS/54319/2002Biotope-Classification, Mapping and Modelling of Azores Littoral Biotopes, and CIRN-Centro de Investigação de Recursos Naturais, both from Fundação para a Ciência e Tecnologia (Portugal). The work performed in the present study complies with the current laws of Portugal.

\section{References}

Barker, B. A. J., I. Helmond, N. J. Bax, A. Williams, S. Davenport \& V. A. Wadley, 1999. A vessel-towed camera platform for surveying seafloor habitats of the continental shelf. Continental Shelf Research 19: 1161-1170.

Bullimore, B. \& K. Hiscock, 2001. Procedural Guideline No. 3-12 Quantitative surveillance of sublittoral rock biotopes and species using photographs. In Davies, J., J. Baxter, M. Bradley, D. Connor, J. Khan, E. Murray, W. Sanderson, C. Turnbull \& M. Vincent (eds), Marine Monitoring Handbook. Joint Nature Conservation Committee.

Clarke, K. R. \& R. M. Warwick, 2001. Change in marine communities: an approach to statistical analysis and interpretation (2nd edition). PRIMER-E, Plymouth. 
Collie, J. S., G. A. Escanero \& P. C. Valentine, 2000. Photographic evaluation of the impacts of bottom fishing on benthic epifauna. ICES Journal of Marine Sciences 57: 987-1001.

Ducrotoy, J. P. A. \& S. D. Simpson, 2001. Developments in the application of photography to ecological monitoring, with reference to algal beds. Aquatic Conservation: Marine \& Freshwater Ecosystems 11: 123-135.

Hawkins, S. J. \& H. D. Jones, 1992. Marine field course guide. 1. rocky shores. Marine Conservation Society. Immel Pub., London.

Ishii, K., H. Takahashi, K. Odal, T. Kojim, H. Soed, K. Takemoto, M. Hiwad \& S. Sameshimal, 1998. 3-D analysis of behavioral responses of aquatic life using stereo video imagery. OCEANS '98 Conference Proceedings, 1(28): 267-271.

Kostylev, V. E., B. J. Todd, G. B. J. Fader, R. C. Courtney, G. D. M. Cameron \& R. A. Pickrill, 2001. Benthic habitat mapping on the scotian shelf based on multibeam bathymetry, surficial geology and sea floor photographs. Marine Ecology Progress Series 219: 121-137.

Lobsigerl, U., G. E. Hoar \& B. D. Johnson, 1986. Time lapse underwater photography system with event sensor Capability. OCEANS 18: 19-23.

Lund-Hansen, L. C., E. Larsen, K. T. Jensen, K. N. Mouritsen, C. Cristiansen, T. J. Andersen \& G. Vølund, 2004. A new video and digital camera system for studies of the dynamics of microtopographic features on tidal flats. Marine Geosources and Geotechnolgy 22: 115-122.

Magorrian, B. H. \& M. Service, 1998. Analysis of underwater visual data to identify the impact of physical disturbance on horse mussel (Modiolus modiolus) Beds. Marine Pollution Bulletin 36(5): 354-359.

Neto, A. I., 1997. Studies on algal communities of São Miguel, Azores. PhD Thesis. Universidade dos Açores, Ponta Delgada.

Neto, A. I., 2000. Ecology and dynamics of two intertidal algal communities on the littoral of the island of São Miguel (Azores). Hydrobiologia 432: 135-147.
Norris, J. G., S. Wyllie-Echeverria, T. Mumford, A. Bailey \& T. Turner, 1997. Estimating basal area coverage of subtidal seagrass beds using underwater videography. Aquatic Botany 58(3-4): 269-287.

Pech, D., A. R. Condal, E. Bourget \& P. Ardisson, 2004. Abundance estimation of rocky shore invertebrates at small spatial scale by high-resolution digital photography and digital image analysis. Journal of Experimental Marine Biology and Ecology 299: 185-199.

Singh, H, J. Howland, D. Yoerger \& L. Withcomb, 1998. Quantitative photomosaiking of underwater imagery. In Proceedings of the OCEANS Conference. IEEE, Nice.

Tkachenko, K. S., 2005. An evaluation of the analysis system of video transects used to sample subtidal epibiota, Journal of Marine Biology and Ecology 318: 1-9.

Turnbull C. \& J. Davies, 2001. Procedural guidelines. In Davies, J., J. Baxter, M. Bradley, D. Connor, J. Khan, E. Murray, W. Sanderson, C. Turnbull \& M. Vincent (eds), Marine Monitoring Handbook. Joint Nature Conservation Committee.

Van Rooij, J. M. \& J. J. Videler, 1996. A simple field method for stereo-photographic length measurement of freeswimming fish: merits and constraints. Journal of Experimental Marine Biology and Ecology 195: 237-249.

Wallenstein, F. F. M. M. \& A. I. Neto, 2006. Intertidal rocky shore biotopes of the Azores: a quantitative approach. Helgoland Marine Research 60: 196-206.

Wallenstein F. F. M. M., A. I. Neto, N. V. Álvaro \& I. Tittley, in press. Subtidal rocky shore communities of the Azores: developing a biotope survey method. Journal of Coastal Research (accepted 12 April 2006).

Wallenstein, F. F. M. M., A. I. Neto, N. V. Álvaro \& C. I. Santos, submitted. Algae based biotopes of the Azores (Portugal): spatial and seasonal variation. Aquatic Ecology.

Winer, B. J., 1971. Statistical Principles in Experimental Design, McGraw-Hill, Tokyo. 